Vol. 1 No. 2 Desember 2021, e-ISSN : 2807-8659 | p-ISSN : 2807-8829

\title{
PENINGKATAN PRESTASI BELAJAR FISIKA MELALUI METODE EKSPERIMEN SISWA KELAS XI MIA 1 SMAN 3 BENGKALIS
}

\author{
SURYANI \\ SMA Negeri 3 Bengkalis \\ Email : sursf76@gmail.com
}

\begin{abstract}
ABSTRAK
Penelitian tindakan kelas menggunakan metode eksperimen sebagai upaya peningkatan prestasi belajar fisika siswa. Pembelajaran metode eksperimen adalah cara belajar mengajar yang melibatkan siswa mengalami dan membuktikan sendiri proses dari hasil percobaan itu. Dengan eksperimen diharapkan siswa benar-benar dapat memahami konsep fisika yang dipelajari. Masalah yang mau dipecahkan adalah rendahnya prestasi belajar fisika yang ditunjukkan oleh hasil belajar fisika siswa kelas XI MIA 1 di SMA Negeri 3 Bengkalis. Penelitian ini terdiri dari 2 siklus, pada setiap siklus terdiri dari 4 tahapan, yaitu Perencanaan, Pelaksanaan, Observasi dan Refleksi. Penelitian ini melibatkan 23 orang siswa kelas X1 MIA 1 SMA Negeri 3 Bengkalis yang terdiri dari 10 siswa laki-laki dan 13 siswa perempuan. Sebelum diterapkannya metode eksperimen, persentase ketuntasan belajar yaitu sebesar 17,39 \%, kemudian setelah dilaksanakan pembelajaran siklus 1 dengan menggunakan motode eksperimen ada peningkatan persentase ketuntasan belajar menjadi 43,48 \%. Pada siklus 2 berhasil mencapai persentase ketuntasan belajar 73,91\%. Hasil penelitian menunjukkan bahwa terjadi peningkatan prestasi belajar siswa seiring dengan diterapkannya metode eksperimen. Dengan demikian, penerapan metode eksperimen dapat meningkatkan prestasi belajar fisika siswa kelas XI MIA 1 SMA Negeri 3 Bengkalis.
\end{abstract}

Kata Kunci : Metode Eksperimen, Prestasi Belajar Fisika.

\section{ABSTRACT}

Classroom action research on using experiment methods to inprove students physics learning achievement. Experimental learning method is a way of teaching and learning that involves students experiencing and proving themselves into process of the experimental results. With experiments, it is hoped that students can really understand the physics concepts being studied. The problem to be solved is the low achievement in learning physics as shown by the physics learning outcomes of class XI MIA 1 students at SMA Negeri 3 Bengkalis. This study consisted of 2 cycles, in each cycle consisting of 4 stages, namely Planning, Implementation, Observation and Reflection. This study involved 23 students of class X1 MIA 1 SMA Negeri 3 Bengkalis consisting of 10 male students and 13 female students. Before the implementing of the experimental method, the percentage of learning completeness was $17.39 \%$, then after the first cycle of learning using the experimental method there was an increase in the percentage of learning completeness to $43.48 \%$. In the second cycle succeeded in achieving the percentage of learning completeness $73.91 \%$. The results showed that there was an increase in student achievement along with the implementation of the experimental method. Thus, the application of the experimental method can improve the physics learning achievement of class XI MIA 1 SMA Negeri 3 Bengkalis.

Keywords: Experimental Method, Physics Learning Achievement.

\section{PENDAHULUAN}

Pendidikan harus diselenggarakan secara sistematis guna mencapai tujuan pendidikan. Keberhasilan atau prestasi belajar siswa dipengaruhi oleh pendidikan karena kualitas pendidikan yang bagus akan meningkatkan prestasi belajar yang lebih baik (Lovisia, 2019:115). Hal ini tidak terlepas dari proses belajar mengajar yang didalamnya terdapat komponen; pengajar, siswa yang belajar, materi yang diajarkan, metode atau strategi pembelajaran yang tepat. Hamalik (2008:27) menjelaskan bahwa belajar adalah semua aktivitas mental atau psikis 
yang dilakukan seseorang sehingga menimbulkan perubahan tingkah laku yang berbeda antara sesudah belajar dengan sebelum belajar. Pembelajaran yang aktif ditandai adanya rangkaian terencana yang melibatkan siswa secara lansung, komprehensif, baik fisik, mental maupun emosi.

Guru harus mampu meningkatkan prestasi belajar siswa. Prestasi belajar dapat diartikan sebagai penguasaan pengetahuan atau keterampilan yang dikembangkan oleh mata pelajaran lazimnya ditunjukkan dengan nilai yang diberikan oleh guru (Tirtonegoro, 1984:43). Faktorfaktor yang mempengaruhi prestasi belajar siswa adalah faktor intern dan faktor ekstern. Faktor intern (dari dalam), yaitu faktor yang dapat mempengaruhi hasil belajar yang berasal dari diri seseorang yang sedang belajar itu sendiri, meliputi : faktor fisiologis (fisik) dan faktor psikologis (mental/kejiwaan). Sementara Faktor Ekstern (dari luar), yaitu faktor yang berasal dari luar diri siswa yang dapat mempengaruhi hasil belajar, meliputi : faktor lingkungan dan faktor instrumen/alat (kurikulum, program guru pengajar, sarana dan prasarana) (Dimyati \& Mudjiono, 2006:236).

Tujuan utama pembelajaran IPA terutama mata pelajaran fisika adalah siswa memahami konsep-konsep IPA secara sederhana dan berkesinambungan dan mampu menggunakan metode ilmiah, serta dapat menerapkan dalam kehidupan sehari-hari. Ini sesuai pendapat Broukhous dalam Druxes yang dikutip oleh Azhar (2008:7) bahwa pembelajaran fisika merupakan pelajaran tentang kejadian alam, yang memungkinkan penelitian dengan percobaan, pengukuran apa yang didapat, penyajian secara matematis dan berdasarkan peraturan peraturan umum. Jadi fisika mempelajari tentang konsep-konsep, struktur-struktur kejadian dan peristiwa alam melalui percobaan sehingga dalam fisika itu mencari hubungan antara konsep-konsep dan struktur-struktur fisika melalui penalaran yang pada akhirnya siswa dapat menyimpulkan sendiri hasil belajarnya. Salah satu upaya guru dalam menciptakan suasana belajar yang aktif, kreatif, efektif dan menyenangkan dalam pembelajaran yakni dengan menggunakan metodemetode yang tepat dan alat peraga yang memadai.

Metode pembelajaran dapat diartikan sebagai cara yang digunakan untuk mengimplementasikan rencana yang sudah disusun dalam bentuk kegiatan nyata dan praktis untuk mencapai tujuan pembelajaran. Terdapat beberapa metode pembelajaran yang dapat digunakan untuk mengimplementasikan strategi pembelajaran, diantaranya : (1) ceramah; (2) demonstrasi; (3) diskusi; (4) simulasi; (5) percobaan/ekperimen laboraturium; (6) pengalaman lapangan; (7) brainstorming; (8) debat; (9) simposium, dan sebagainya (Sudrajat, 2008:41).

Metode Eksperimen adalah cara penyajian pelajaran dimana siswa melakukan percobaan dengan mengalami sendiri sesuatu yang dipelajari (Syaiful, 2002:95). Setiap siswa harus berpartisipasi aktif dalam melakukan eksperimen, melakukan demonstrasi, diskusi kelas dan pengalaman belajar lain yang relevan (Chebii et al, 2012:1291). Dalam proses belajar mengajar dengan metode eksperimen, siswa diberi kesempatan untuk mengalami sendiri atau melakukan sendiri mengikuti suatu proses mengamati suatu objek, keadaan atau proses sesuatu. Adapun prosedur metode eksperimen adalah : a) perlu dijelaskan tujuan eksperimen, b) memberi penjelasan kepada siswa tentang alat-alat serta bahan bahan yang akan dipergunakan dalam eksperimen, c) selama eksperimen, guru harus mengawasi pekerjaan siswa, d) setelah eksperimen, mengumpulkan hasil penelitian, mendiskusikan di kelas, dan mengevaluasi dengan tes atau tanya jawab (Roestiyah, 2001:81). Metode eksperimen memiliki kelebihan dan kekurangan. Kelebihan metode eksperimen adalah : (1) membuat siswa lebih percaya pada kesimpulan berdasarkan percobaan sendiri dari pada hanya menerima kata guru atau buku, (2) siswa aktif terlibat mengumpulkan fakta, informasi atau data yang diperlukan melalui percobaan yang dilakukannya, (3) dapat digunakan prosedur metode ilmiah dan berfikir ilmiah, (4) memperkaya pengalaman dengan hal-hal yang bersifat objektif dan realistis, (5) hasil belajar menjadi kepemilikan siswa yang tahan lama. Sedangkan kelemahan metode eksperimen adalah : (1) memerlukan peralatan percobaan yang komplit, (2) dapat menghambat laju pembelajaran dalam penelitian yang memerlukan waktu yang lama, (3) menimbulkan kesulitan bagi guru dan siswa apabila kurang pengalaman dalam penelitian/eksperimen, (4) kegagalan dan kesalahan 
dalam bereksperimen akan berakibat pada kesalahan menyimpulkan (Sumantri \& Permana, 1999:158).

Berdasarkan hasil Ulangan Harian untuk pelajaran Fisika siswa Kelas XI MIA 1 Semester Ganjil SMA Negeri 3 Bengkalis Kabupaten Bengkalis Tahun Pelajaran 2021/2022 pada materi Keseimbangan dan Dinamika Rotasi disimpulkan bahwa masih banyak siswa belum tuntas atau belum mencapai Kriteria Ketuntasan Minimal $(\mathrm{KKM}=70)$. Terlihat dari 23 siswa kelas XI MIA 1 hanya 4 orang siswa yang mendapat nilai di atas KKM (70) dengan nilai rata-rata kelas 27,39. Sementara tingkat ketuntasan kelasikal hanya mencapai 17,39\%. Permasalahan yang timbul di antaranya adalah : 1) Banyak siswa yang masih kurang memahami penjelasan guru dalam proses belajar mengajar. 2) Selama proses belajar mengajar, siswa kurang aktif karena proses pembelajaran lebih didominasi oleh guru. 3) Metode yang dipakai kurang menarik dan cenderung monoton karena tidak ada variasi dengan menerapkan metode yang lain. 4) Siswa kurang antusias dalam mengikuti proses pembelajaran daring/tatap muka. 5) Hasil belajar tes ulangan harian rendah.

Setelah menganalisa permasalahan tersebut dapat diatasi dengan mencoba mengubah metode eksperimen pada kegiatan pembelajaran berikutnya. Metode eksperimen merupakan metode pembelajaran yang menempatkan siswa sebagai subyek yang aktif. Metode pembelajaran eksperimen melibatkan secara maksimal seluruh kemampuan siswa untuk mencari dan menyelidiki secara sistematis, logis, analisis, kritis melalui eksperimen (Mulyasa, 2004 : 234). Oleh sebab itu, penulis mengadakan penelitian untuk memperbaiki pembelajaran dengan judul : "Peningkatan Prestasi Belajar Fisika Melalui Metode Eksperimen Siswa Kelas XI MIA 1 SMAN 3 Bengkalis”.

\section{METODE PENELITIAN}

Subjek penelitian ini adalah siswa kelas XI MIA 1 Semester Ganjil SMA Negeri 3 Bengkalis tahun pelajaran 2021/2022 dengan jumlah 23 orang dengan pertimbangan kelas tersebut kemampuan siswa dilihat dari nilai prestasi hasil belajar fisika, lebih banyak nilai rendah (di bawah KKM) dibanding dengan kelas yang lain. Pelaksanaan penelitian ini selama 4 bulan dari bulan Agustus sampai dengan bulan November tahun 2021 terdiri dari 2 siklus. Menurut Arikunto yang dikutip oleh Suryani (2019:40) bahwa prosedur penelitian tindakan kelas menggunakan minimal dua siklus, jika guru belum merasa puas maka dapat melanjutkan ke siklus yang ketiga dengan langkah-langkah setiap siklus, yaitu tahap perencanaan (planning), tahap pelaksanaan tindakan (acting), tahap pengamatan (observing) dan tahap refleksi (reflecting).

Teknik yang digunakan dalam pengumpulan data adalah teknik tes tertulis dan instrumen pengumpulan data berupa lembar kerja siswa (LKS) dan lembar hasil belajar (lembar ulangan dan tugas siswa).

Data dianalisis dengan menggunakan analisis deskriptif (analisis ketuntasan hasil belajar siswa). Tingkat keberhasilan belajar siswa secara individu untuk pelajaran fisika di kelas XI MIA 1 berdasarkan Kriteria Ketuntasan Minimal (KKM) yaitu 70 (70 \%). Sedangkan ketuntasan hasil belajar secara klasikal sebesar $85 \%$. Persentase ketuntasan dihitung dengan menggunakan rumus :

1. Ketuntasan Belajar Siswa Individu (KBSI) :

$$
K B S I=\frac{\text { Skor yang Diperoleh Siswa }}{\text { Skor Maksimal }} \times 100 \%
$$

(Tim Pustaka Yustisia, 2008:362)

2. Ketuntasan Belajar Siswa Klasikal (KBSK) :

$$
K B S K=\frac{\sum \text { Siswa yang Tuntas }}{\sum \text { Seluruh Siswa }} \times 100 \%
$$

(Depdiknas, 1994:24) 
Prosedur penelitian melalui tahapan tindakan, dimulai dari perencanaan, pelaksanaan/tindakan, observasi dan refleksi. Pada tahap perencanaan telah dipersiapkan : 1) Rencana Pelaksanaan Pembelajaran (RPP) melalui metode eksperimen di labor, 2) semua bahan/peralatan praktikum di laboratorium fisika. 3) alat instrumen penilaian termasuk Lembar Kerja Siswa (LKS) yang berisi pertanyaan. Pertanyaan ini membantu siswa mengumpulkan informasi dan membangun argument berdasarkan bukti (Lee at al, 2006:157) dan 4) lembar jawaban siswa. b. Tahap Tindakan, 1) Pendahuluan, yang meliputi kegiatan persiapan sebelum belajar, do'a, apersepsi dan motivasi materi serta menyampaikan tujuan belajar. 2) Kegiatan inti, meliputi : memberi tes awal dan mempersiapkan alat/melaksanakan eksperimen dalam kelompok, mempresentasikan hasil kerja, mereward/penghargaan. 3) Penutup, meliputi : refleksi kegiatan yang dilakukan, mengumpulkan LKS siswa. c. Observasi, pengamatan dilakukan selama proses pembelajaran berlangsung. Dalam pengamatan diungkap segala peristiwa, aktivitas siswa maupun respon siswa terhadap teknik/metode pembelajaran. Selanjutnya data yang diperoleh dalam siklus 1 dijadikan sebagai bahan refleksi.

Demikian seterusnya dilakukan berulang-ulang selama 2 siklus. Proses tindakan siklus 2 merupakan kelanjutan dari siklus 1 . Hal-hal yang kurang pada siklus 1 diperbaiki pada siklus 2 .

\section{HASIL DAN PEMBAHASAN}

\section{HASIL}

Prasiklus

Sebelum penelitian dilaksanakan, pembelajaran hanya bersifat monoton, yaitu guru hanya menyampaikan materi belajaran fisika dengan ceramah dan siswa cendrung mendengarkan sehingga siswa akan bosan dan tidak tertarik mengikuti pembelajaran serta suasana kelas tidak kondusif sehingga akan berdampak pada siswa dan proses pembelajaran kurang berhasil secara optimal. Hal tersebut dapat dilihat dari prestasi hasil belajar ulangan harian fisika masih kurang dari harapan. Hasil ulangan harian fisika dapat dilihat pada tabel 1 berikut :

Table 1. Ketuntasan Hasil Belajar Prasiklus

\begin{tabular}{cccc}
\hline No & Hasil Belajar Siswa & Jumlah & Persentase (\%) \\
\hline 1. & Tuntas & 4 & $17,39 \%$ \\
2. & Tidak Tuntas & 19 & $82,61 \%$ \\
& Jumlah & 23 & 100
\end{tabular}

Dari tabel 1 bahwa hasil nilai ulangan harian, prestasi hasil belajar fisika masih banyak siswa yang nilainya di bawah KKM (70) hanya memperoleh nilai rata-rata 27,39 dengan ketuntasan mencapai $17,39 \%$. Berdasarkan nilai tersebut, dapat dilihat bahwa sangat rendahnya prestasi belajar dalam proses pembelajaran fisika.

\section{Siklus 1}

Pelaksanaan penelitian tindakan kelas ini dilakukan dalam 2 siklus. Tiap siklus terdiri dari 4 tahap yaitu perencanaan, pelaksanaan tindakan, observasi dan refleksi. Dalam pelaksanaan siklus 1, pembelajaran dilakukan dengan penerapan metode eksperimen, yang sebelumnya diadakan tes awal untuk mengetahui tingkat pemahaman siswa terhadap materi yang akan diajarkan. Kemudian siswa dibagi kelompok untuk melakukan ekperimen yang telah ditentukan. Hasil eksperimen didiskusikan dalam kelompok kemudian dipresentasikan di depan kelas.

Berdasarkan lembar observasi, aktivitas siswa dan hasil eksperimen serta hasil tes baik tes awal maupun tes akhir maka diperoleh data-data pada tindakan siklus 1. Pada siklus 1, siswa belum terbiasa belajar secara berkelompok melalui eksperimen, sehingga diskusi kelompok eksperimen/percobaan yang dilakukan belum maksimal. Akibatnya banyak siswa bertanya 
tentang cara penggunaan alat. Siswa masih takut bertanya maupun mengungkapkan pendapat dalam diskusi presentasi. Hanya 1 atau 2 orang saja yang sudah aktif jika diberi umpan oleh guru. Siswa belum bisa memaksimalkan waktu yang diberikan untuk menyelesaikan tugas sehingga hasil tes akhir siklus 1 diperoleh seperti pada tabel 2 di bawah ini :

Table 2. Ketuntasan Belajar Siklus 1

\begin{tabular}{cccc} 
No & Hasil Belajar Siswa & Jumlah & Persentase (\%) \\
\hline 1. & Tuntas & 10 & $43,48 \%$ \\
2. & Tidak Tuntas & 13 & $56,52 \%$ \\
& Jumlah & 23 & $100 \%$ \\
\hline
\end{tabular}

Berdasarkan tabel 2, prestasi hasil belajar siswa pada siklus 1 yang diperoleh sudah mengalami peningkatan jika dibandingkan dengan prestasi hasil belajar pada prasiklus yaitu nilai rata-rata kelas pada siklus 2 sudah meningkat menjadi 48,04 dengan persentase ketuntasan mencapai 43,48 \%. Berdasarkan hasil tersebut ada peningkatan hasil belajar siswa, namun demikian hasil belajar masih belum seperti yang diharapkan dengan kondisi masih banyak siswa yang belum tuntas dalam belajar. Oleh karena itu dibutuhkan siklus selanjutnya yaitu siklus 2 dalam meningkatkan prestasi belajar siswa tersebut.

\section{Siklus 2}

Pelaksanaan tindakan siklus 2 yang teramati adalah aktivitas siswa dalam melakukan ekperimen di labor terlihat aktif dan saling bekerjasama menyelesaikan data-data eksperimen yang dilakukan masing-masing kelompok, keberanian siswa bertanya kepada guru dan mengemukakan pendapat serta berkomentar atas pendapat siswa lainnya, guru sudah lebih memperhatikan dan memberi bimbingan serta motivasi dalam proses pembelajaran. Peningkatan prestasi belajar yang ditunjukkan dengan nilai tes siklus 2 sangat signifikan, terlihat seperti pada tabel 3 berikut :

Table 3. Ketuntasan Belajar Siklus 2

\begin{tabular}{cccc} 
No & Hasil Belajar Siswa & Jumlah & Persentase (\%) \\
\hline 1. & Tuntas & 17 & $73,91 \%$ \\
2. & Tidak Tuntas & 6 & $26,09 \%$ \\
& Jumlah & 23 & $100 \%$ \\
\hline
\end{tabular}

Dari tabel 3 hasil tes tindakan siklus 2, siswa sudah mencapai ketuntasan belajar meningkat. Nilai rata-rata kelas mencapai 80,23 dengan ketuntasa klasikal 73,91\%. Meskipun tidak mencapai ketuntasan klasikal seperti yang telah ditetapkan, namun pada siklus 2 sudah ada peningkatan prestasi hasil belajar melalui metode eksperimen.

Secara keseluruhan hasil penelitian yang telah dimulai dari prasiklus, siklus 1 dan siklus 2 dapat digambarkan pada tabel 4 sebagai berikut :

Table 4. Analisis Data Prasiklus Sampai Dengan Siklus 2

\begin{tabular}{ccccc}
\hline No & Hasil Belajar Siswa & Tuntas & $\begin{array}{c}\text { Tidak } \\
\text { Tuntas }\end{array}$ & $\begin{array}{c}\text { Persentase } \\
\text { Ketuntasan }(\%)\end{array}$ \\
\hline 1. & Prasiklus & 4 & 19 & $17,39 \%$ \\
2. & Siklus 1 & 10 & 13 & $43,48 \%$ \\
3. & Siklus 2 & 17 & 6 & $73,91 \%$ \\
\hline
\end{tabular}

Sehingga peningkatan prestasi hasil belajar siswa dari prasiklus sampai dengan siklus 2, juga dapat dilihat pada grafik 1 berikut ini : 


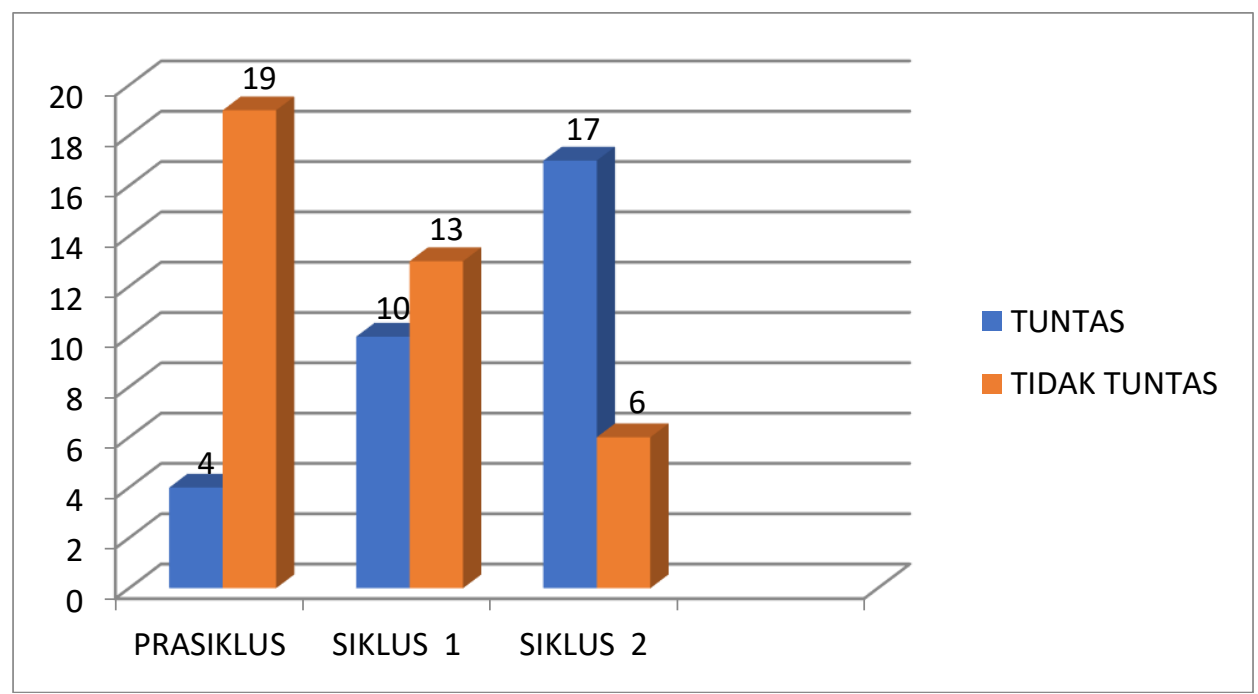

Grafik 1. Hasil Belajar Prasiklus Sampai Dengan Siklus 2

\section{Pembahasan}

Masalah yang hendak dipecahkan dalam penelitian ini adalah rendahnya prestasi belajar siswa yang ditunjukkan dengan hasil belajar siswa kelas XI MIA 1 SMA Negeri 3 Bengkalis dalam pembelajaran fisika. Melalui metode eksperimen, diharapkan dapat meningkatkan prestasi belajar fisika di kelas XI MIA 1. Kenyataan yang terjadi, dari hasil nilai ulangan belajar fisika masih banyak siswa yang nilainya di bawah KKM (70). Dari 23 orang siswa kelas XI MIA 1 hanya 4 orang $(17,39 \%)$ saja yang tuntas dan 19 orang $(82,61 \%)$ siswa yang tidak tuntas. Kondisi tersebut disebabkan oleh beberapa faktor seperti; strategi pembelajaran yang diterapkan oleh guru yang masih konvensional, guru adalah satu-satunya sumber belajar. Sedangkan seiring dengan reformasi pendidikan terjadi juga perubahan paradigma pembelajaran yang lebih menekankan pada pembelajaran yang bersifat siswa yang aktif menemukan masalah yang dipelajari, guru hanya berfungsi sebagai fasilitator proses pembelajaran. Maka tindakan yang dipilih dalam meningkatkan hasil belajar siswa adalah penerapan metode ekperimen karena pembelajaran yang efektif adalah pembelajaran yang menyediakan kesempatan pada siswa untuk belajar sendiri atau melakukan aktivitas/pengalaman sendiri (Muslich, 2008:75).

Prosedur dalam penelitian ini terdiri atas 2 siklus. Setiap siklus, terdiri dari 3 kali tatap muka (pertemuan) sesuai dengan empat tahapan setiap siklus, yaitu perencanaan, tindakan, pengamatan dan refleksi. Sebelum melaksanakan pembelajaran, ada beberapa hal yang perlu dilaksanakan, antara lain : guru membuat rencana pelaksanaan pembelajaran (RPP), guru menyusun Petunjuk Praktikum/Kerja (LKS) dan Lembar Jawaban Siswa, guru mempersiapkan alat dan bahan yang akan digunakan untuk praktikum. Menurut Arikunto, et al dalam Warsiki (2018:4) menyatakan perencanaan dimulai dengan menetapkan berbagai alternatif tindakan pemecahan masalah kemudian dipilih tindakan yang paling menjanjikan hasil terbaik yang dapat dilakukan.

Pada siklus 1 terlihat siswa belum aktif dalam mengikuti eksperimen, mereka masih terlihat belum terbiasa praktik sehingga banyak yang tidak tahu penggunaan alat serta malu bertanya maupun mengeluarkan pendapat saat diskusi presentasi. Dari hasil pengamatan pada siklus 1 ini menunjukkan bahwa siswa belum dapat menyesuaikan diri terhadap kegiatan pembelajaran melalui praktikum untuk memahami konsep/materi lewat pengalaman sendiri dan guru masih kurang mampu mengkondisikan kelas menjadi kelas yang kondusif. Jadi pelaksanaan pembelajaran metode eksperimen belum maksimal. Apalagi dengan waktu yang relatif singkat. Oviana (2013:9) mengatakan kegiatan pembelajaran dengan metode eksperimen dapat memberikan kesempatan siswa menemukan konsep sendiri melalui observasi dengan daya nalar, daya pikir kreatif dan efektif.

Prestasi hasil belajar siswa pada siklus 1 yang diperoleh sudah mengalami peningkatan jika dibandingkan dengan prestasi hasil belajar pada prasiklus dan tes awal. Dari nilai rata-rata 


\section{EDUCATOR : Jurnal Inovasi Tenaga Pendidik dan Kependidikan Vol. 1 No. 2 Desember 2021, e-ISSN : 2807-8659 | p-ISSN : 2807-8829}

kelas pada prasiklus $(27,39)$ dan nilai rata-rata kelas tes awal sebesar 33,26 meningkat menjadi 48,04. Sedangkan pada ketuntasan klasikal dari 17,39 \% kemudian 21,74 \% sudah meningkat menjadi 43,48 \%. Pada kegiatan tes akhir siklus 1 terdapat 10 orang siswa $(43,48 \%)$ yang tuntas dan 13 orang siswa $(56,52 \%)$ yang tidak tuntas dari total 23 orang siswa.

Untuk kegiatan observasi dilaksanakan bersamaan dengan proses pembelajaran berlangsung, observer dilaksanakan oleh teman guru sejawat agar pengamatan berlangsung secara efektif dan hasilnya bisa objektif. Yang dilakukan oleh observer pada bagian ini adalah; mencatat semua kegiatan yang terjadi melalui lembaran observasi, meliputi : memperhatikan demonstrasi/penjelasan guru, keaktifan siswa mengajukan pertanyaan/tanggapan, kinerja/kerjasama siswa dalam kelompok eksperimen, tingkah laku dalam laboratorium/kelas, mengerjakan tugas kelompok tepat waktu, keaktifan dalam diskusi kelas.

Pada pembelajaran siklus 2 siswa sudah terlihat aktif dibandingkan pada prasiklus dan siklus 1. Pada siklus 2 ini siswa dalam kelompok terlihat lebih semangat dalam menyelesaikan tugas praktikum yang diberikan guru. Kekurangan dalam siklus 1 harus menjadi bahan pertimbangan yang penting bagi guru pada saat penyusunan siklus 2, sebab siklus 2 merupakan penyempurnaan yang lebih baik dari siklus 1 .

Pada siklus 2 guru sudah lebih memperhatikan dan memberi bimbingan serta motivasi dalam proses pembelajaran melalui metode eksperimen. Pada siklus 2, siswa yang mencapai ketuntasan belajar meningkat yaitu dari jumlah 23 orang siswa yang tuntas sebanyak 17 orang siswa $(73,91 \%)$ dengan rata-rata nilai 80,23, sedangkan yang tidak tuntas hanya 6 orang siswa (26,09 \%). Pada siklus 2 sudah ada peningkatan pencapaian prestasi hasil belajar melalui metode eksperimen meskipun tidak mencapai ketuntasan klasikal 85\%. Hasil ini menunjukkan bahwa metode eksperimen telah berhasil meningkatkan prestasi belajar. Hasil yang diperoleh dalam penelitian ini sejalan dengan penelitian yang dilakukan sebelumnya oleh Nastitik dalam jurnal Tajdidukasi Volume VIII No. 1 Januari 2018 yang menyatakan bahwa penerapan metode eksperimen memiliki dampak positif dalam meningkatkan prestasi belajar siswa.

Dari hasil tersebut diketahui bahwa pembelajaran dengan menggunakan metode eksperimen dapat meningkatkan persentase ketuntasan belajar dengan signifikan. Hal ini menunjukkan bahwa pemahaman siswa dalam pembelajaran dengan menggunakan metode eksperimen dapat meningkatkan prestasi belajar siswa yang ditunjukkan pada nilai hasil belajar siswa. Oleh karena itu hipotesis tindakan dapat tercapai, menandakan bahwa penelitian tindakan dinyatakan berhasil dalam meningkatkan prestasi belajar siswa.

\section{KESIMPULAN}

Berdasarkan penelitian tindakan kelas ini dapat disimpulkan bahwa pembelajaran fisika dengan menggunakan metode eksperimen dapat meningkatkan prestasi belajar siswa kelas XI MIA 1 SMA Negeri 3 Bengkalis tahun pelajaran 2021/2022. Peningkatan prestasi belajar dibuktikan dengan adanya peningkatan persentase ketuntasan hasil belajar siswa. Sebelum diterapkannya metode eksperimen, persentase ketuntasan belajar sebesar (17,39\%), kemudian setelah dilaksanakan pembelajaran siklus 1 dengan metode eksperimen ada peningkatan persentase menjadi 43,48 \%. Pada siklus 2 berhasil mencapai persentase 73,91\%. Artinya prestasi belajar siswa melalui metode eksperimen lebih baik karena dibuktikan dengan adanya peningkatan nilai hasil belajar siswa dengan melihat peningkatan ketuntasan belajar siswa dari prasiklus sampai dengan siklus 2 .

Mengingat pentingnya metode eksperimen untuk meningkatkan hasil belajar siswa, diharapkan pelaksanaan pembelajaran dengan metode eksperimen mata pelajaran fisika agar dapat dilakukan tidak hanya sampai pada selesainya penelitian ini saja, akan tetapi dilanjutkan dan dilaksanakan secara kontinu sebagai program untuk meningkatkan semangat dan mengurangi kejenuhan siswa dalam proses pembelajaran. Hal ini sesuai juga dengan tuntutan guru untuk memantapkan kompetensinya, memperbanyak variasi mengajar dan mengenal metode atau model-model pembelajaran dalam meningkatkan mutu pendidikan anak bangsa. 


\section{DAFTAR PUSTAKA}

Azhar. (2008). Pendidikan Fisika dan Keterkaitannya dengan Laboratorium. Jurusan PMIPA FKIP Universitas Riau. Jurnal Geliga Sains. 2 (1), 7-12.

Chebii, R., Wachanga, S., \& Kiboss, J. (2012). Effects of Sciences Process Skills Mastery Learning Approach on Students Acquisition of Selected Chemistry Practical Skills in School. Creative Education. 3 (1), 1291-1296.

Depdiknas. (2004). Rambu-Rambu Penetapan Ketuntasan Belajar Minimal dan Analisis Hasil Pencapaian Standar Ketuntasan Belajar. Jakarta: Depdiknas.

Dimyati, \& Mudjiono. (2006). Belajar dan Pembelajaran. Jakarta: Depdikbud bersama PT. Rineka Cipta.

Hamalik, O. (2008). Proses Belajar Mengajar. Jakarta: Bumi Aksara.

Lee, W. J., Puspitasari, K. A., \& Kim, H. Y., et al. (2006). The Effect of Guided Inquiry Question on Students Critical Thinking Skills and Satisfaction in Online Argumentation. Journal of Florida. 1 (1), 156-162.

Lovisia, E. (2019). Penerapan Metode Eksperimen Terhadap Hasil Belajar Siswa Kelas XI SMA Negeri 2 Muara Beliti. LP4MK STKIP PGRI Lubuk Lingga. 2 (1), 114-121.

Mulyasa, E. (2004). Kurikulum Berbasis Kompetensi. Bandung: PT. Rosda Karya.

Muslich, M. (2008). Pembelajaran Berbasis Kompetensi dan Kontekstual. Jakarta: Bumi Aksara.

Nastitik. (2018). Penggunaan Metode Eksperimen untuk Meningkatkan Prestasi Belajar IPA siswa SMP Muhammadiyah 2 Bambanglipuro. Jurnal Tajdidukasi. 8 (1), 143-155.

Oviana, W., \& Maulidar. (2013). Penggunaan Metode Eksperimen pada Pembelajaran Materi Sifat Bahan dan Kegunaannya Terhadap Hasil dan Respon Belajar Siswa Kelas IV MIN Tungkob Aceh Besar. Jurnal Ilmiah DIDAKTIK. 8 (2), 336-350.

Roestiyah. (2001). Strategi Belajar Mengajar. Jakarta: PT. Rineka Cipta.

Sudrajat, A. (2008). Media Pembelajaran . Bandung: CV. Yrama Widya.

Sumantri, M., \& Permana, J. (1999). Strategi Belajar Mengajar. Jakarta: Dirjen Dikti, Depdikbud.

Suryani. (2019). Improvement of Student Physics Learning Outcames Trough Peer Tutor Learning Model of SMA 3 Bengkalis. FKIP University of Publisher: Journal of Educational Sciences. 3 (1), 38-47.

Syaiful, B. D. (2002). Strategi Belajar Mengajar. Jakarta: PT. Rineka Cipta.

Tim. (2008). Panduan Lengkap KTSP (kurikulum Tingkat Satuan Pendidikan). Yogyakarta: Pustaka Yustisia.

Tirtonegoro, S. (1884). Anak Super Normal dan Program Pendidikannya. Jakarta: Bina Aksara. Warsiki, N. M. (2018). Implementasi Metode Eksperimen dalam Meningkatkan Prestasi Belajar IPA. Jurnal Penelitian dan Pengembangan Pendidikan. 2 (1), 1-8. 